\title{
Progress and Enlightenment of America's Electricity Regulatory System Reform
}

\author{
Wang Wei ${ }^{1}$ \\ North China Electric Power University \\ NCEPU \\ Beijing, China \\ 709061680@qq.com
}

\author{
Liu Xuan ${ }^{2}$ \\ North China Electric Power University \\ NCEPU \\ Beijing, China \\ lx15650758321@sina.com
}

\begin{abstract}
In 2015, the "Document No. 9" opened the prelude of new round electric reform. The new round electric power reform has made a lot of achievements, but also some deep problems. The progress of American electric power supervision reform is worth studying and summarizing. By using literature research, case research and other methods, this paper summarizes the experience of the U.S. electric power supervision reform through the study on current situation and regulatory reformation progress of American electric power industry, and then puts forward some suggestions on the electric power supervision revolution for China.
\end{abstract}

Keywords-America's electricity regulation, electric power system, electricity market, electricity reform

\section{INTRODUCTION}

In 2015, new power system reform plan- the 'Document No. 9", was released, which was widely concerned by all circles in the society. It marked the beginning of new round electricity system reform. However, the reform of electric power system can't achieved overnight. This huge, complex and systematic project is bound to be gradual. In the context of globalization, it is necessary to learn from the experience of foreign electric power supervision reformation. This paper studies and summarizes the U.S. electric power regulatory reform's experience, and gives some advises on Chinese electricity supervision reform.

\section{CURRENT STATUS OF AMERICA'S ELECTRICITY REGULATION}

\section{A. Present Situation of American Electric Power Industry}

As a big power production and consumption country, the United States has the largest power industry in the world. In 2016, the average power generation in America was 11.14 billion KWH per day. In terms of energy structure of electric power generation, coal, natural gas and nuclear energy have been the top three in the country. The proportion of coal is decreasing gradually, of natural gas is increasing, and of nuclear energy is almost stable. The power generation scale of natural gas exceeded coal for the first time in 2016, and the share of the three were $30.4 \%, 34.2 \%$ and $19.7 \%$ respectively. It is worth mentioning that the proportion of renewable energy power generation has been increasing, which proportion accounted for $8.42 \%$ in $2016 .{ }^{[1]}$ President Obama proposed

WangWei ${ }^{1}$, Professor, School of Humanities and Social Sciences, NCEPU, The director of the Beijing Energy Development Research Center.

Liu Xuan ${ }^{2}$, Postgraduate, School of Humanities and Social Sciences, NCEPU that $80 \%$ of America's electricity generation would come from clean energy in 2035. Therefore, the American power regulators have strengthened the incentive regulation to increase the use of renewable energy generation, optimized the energy structure of the power industry, and strived to promote the clean development of electricity on the basis of the environmental protection.

\section{B. Status Quo of the America's Electricity Regulatory System}

The U.S. electricity regulation is implemented by two level supervision system - the federal and the state. The federal level regulation mainly focuses on the wholesale and transmission of electricity, and the management of transnational and interstate electric power transactions; the state level supervision places emphasis on electric power distribution and retail in their own jurisdiction area, which is generally not affected by the federal regulatory authorities. At the federal level, the Federal Energy Regulation Commission (FERC) is independent of the president and Congress, which implement regulatory functions mainly through enacting legislation. FERC's major duty is to supervise interstate transmission of electricity, gas and oil. In addition, the institutions that supervise the power industry at the state level are the Public Utilities Committees (PUC) of various states primarily.

The main electricity regulatory agencies in the United States and their responsibilities are as follows:

TABLE I. THE U.S. ELECTRICITY REGULATORY AGENCIES AND THEIR MAIN RESPONSIBILITIES

\begin{tabular}{|l|l|}
\hline \multicolumn{1}{|c|}{ Regulators } & \multicolumn{1}{|c|}{ Main Responsibilities } \\
\hline \multirow{2}{*}{ FERC } & $\begin{array}{l}\text { Regulates the transmission and wholesale sales of electricity } \\
\text { in interstate commerce; Reviews certain mergers and } \\
\text { acquisitions and corporate transactions by electricity } \\
\text { companies; Reviews the siting application for electric } \\
\text { transmission projects under limited circumstances; Licenses } \\
\text { and inspects private, municipal, and state hydroelectric } \\
\text { projects; Protects the reliability of the high voltage interstate } \\
\text { transmission system through mandatory reliability } \\
\text { standards; Monitors and investigates energy markets; } \\
\text { Oversees environmental matters related to natural gas and } \\
\text { hydroelectricityprojects and other matters. }\end{array}$ \\
\hline PUC & $\begin{array}{l}\text { Regulates the electric retail price in the state; Establishes } \\
\text { and supervises the various related organizations in the state; } \\
\text { Designes the organization pattems of electric power markets } \\
\text { according to the state's power development. }\end{array}$ \\
\hline
\end{tabular}




\section{THE PROCESS OF AMERICA'S ELECTRICITY REGULATION}

\section{A. The Background of America's Electric Power Regulatory Reform}

Marketization is one of the prominent manifestations of globalization, which stresses the role of market mechanism. And marketization of the electric power industry is characterized by introducing competition and the balance between competition and supervision. There is no national electricity market in America, but only regional electric power grid, so that the ownership of electricity generation and transmission network is scattered. In these basic circumstances coupled with the tide of market-oriented reform, whether to introduce competition into the power industry or not and how to balance competition and supervision are most important concern in the process of American electricity supervision reform.

\section{B. The Progress of American Electric Power Regulatory Reform}

The U.S. electricity regulatory reform process can be roughly divided into two stages. The first stage had been strengthening supervision before 1970s. The first electricity regulation in the U.S. appeared in Wisconsin in 1907, which was only competitive companies lobbied the government to protect their interests. In order to prevent the monopoly of increasingly powerful private power companies from encroaching on consumers' interests, America set up a government regulatory agency in 1916. In 1930 the Federal Power Commission (FPC) was set up, which initial responsibility is to coordinate the development of federal water power generation for the cabinet members. With the increase of functions, the FPC was renamed the Federal Energy Regulatory Commission (FERC) in 1977. In 1935, the promulgation of the Public Utility Holding Company Act (PUHCA) required the state governments to supervise the retail trade in their own state, and the real regulatory era was opened.

The second stage of reform is to introduce competition. As symbol, the Public Utility Regulatory Policy Act (PURPA) was adopted by the U.S. Congress in 1978. The two oil crisis in 1970s hit the American power industry, and prompted the U.S. to introduce competition into the power generation side. Moreover, further deregulation and free competition had been advocated during the period of President Reagan. The "Order No.888" and " Order No.889" issued in 1996, which stipulated that plant should be separated from grid and the electric power wholesale market should be opened. In 1999, the Regional Transmission Organization (RTO) was proposed to establish in the "Order No.2000" by FERC, which is responsible for dispatch, operation and market supervision of trans-state grid. In 2004, the "independent RTO act" further clarified the construction of the RTO and the ISO (Independent System Operator) as an important part of the future power industry reform. At present, the United States has established 7 typical RTOs or ISOs. The energy policy act enacted in 2005, which clearly defined introducing competition as national power development policy.
California, the bellwether of U.S electricity regulatory reform, introduced competition into the power industry in 1996 and pioneered the American electricity market reform. However, from 2000 to 2001, the power crisis occurred in California-severe power shortage and supply tension led to the collapse of power system, and triggered a series of chain reactions, which eventually resulted in the financial crisis of the electricity market even of the California government. This event not only brought forth an argument about whether to introduce competition into the power industry or not, but also the impact of market competition on the stability of the power system been reexamined, and meanwhile provided a lesson for the reform of electricity market. Therefore, America has shifted its priority from reforming electric power industry to perfecting healthy and stable operation in system construction of the electricity market. In the energy policy act, it not only determines the national electricity policy of introducing competition into the electric power industry, but also makes it clear that one of the FERC's functions is to ensure successful implementation of competitive polices and the wholesale market run well through the more extensive regulatory measures entrusted by Congress.

\section{Basic Experience of American Electric Power Regulatory Reform}

American electric power regulatory reform has achieved remarkable success at home. There is no other power crisis since the "California crisis". The domestic electricity price is in a basic stable state, which guarantees the fair electricity price for consumers; the annual electricity generation volume is equal to the retail volume on the whole; the supervision and competition are coordinated, which keeps the whole power industry in a steady development state; environmental protection is noted while maintaining the normal operation of the power industry; the latest smart grid in the U.S. has been put into use. To a great extent, America's electricity regulation has been benefited effectively from its unique characteristics of electric power supervision reform, which has been upholding the three fundamental points of persisting in law, competition and regulation.

1) Strengthening legalization of regulation, promoting competition and maintaining fair market

Legislation in advance is a major feature in the U.S. electricity regulatory reform process, which is the foundation of its power regulation. Whether the establishment of FERC, NARUC, PUC and other regulators, or the empowerment of regulatory functions and the ways and contents of supervision is realized through laws and regulations. Laws ensure that any organization or individual can complain about illegal activities of the power industry according to these rules and regulations, maintain their legitimate interests and give strong unlawful punishment rights to the FERC and the PUCs of various states. In addition, the federal and state energy laws have explicitly stipulations at power market access mechanism.

Regulating within the law has further promoted competition and maintained fair market. The FERC successively issued "Order NO.888", "Order NO.889", " Order NO.2000" and "independent RTO act" in 1996, 1999 and 2004. Through these laws, it is gradually from the requirement of 
state power companies that own interstate transmission grid should open to all power generation companies, to the proposition of the establishment of regional power grid operation organization, and then to the determination that making the RTO and the ISO as future main parts of reform. At the same time of introducing competition, America efforts to maintain the coordination of competition and supervision through further improvement of supervision. So that it can avoid such unordered competition even the collapse of the power industry in California, and preserve the market equity.

2) Perfect setting of regulatory functions and contents, and good coordination

The supervisory functions of the American power industry are mainly include: electricity price supervision, capacity supervision, supervision of speculation behaviors, the approval of the merger, reorganization and securities issuance of electric power enterprises and so on. For example, there are three principal procedures for electricity price supervision: verifying, adjusting and monitoring the price of electricity. The procedure of approving the electricity price firstly is that the regulated power companies must submit a detailed financial list for their regulators to examine whether the data is true and reasonable or not. The electricity price adjustment program needs the regulated power companies put forward a price adjustment application, and also provide the proof of cost change instructions. After receiving the application, the corresponding regulators would set up a review panel to investigate their price adjustment application seriatim. Monitoring the electricity price is to analyze the price fluctuation of various places according to the price information received by the FERC. If the price is anomalous, it should be transferred to the investigation department for processing. Capacity regulation refers to capacity regulation indicators, includes the adequacy ratio index of market supply and declaration. For instance, the California electric power market sets these two indexes, in order to measure the market power situation of the whole power generation market and a certain generator whether to exercise the market force or not. Moreover, American electricity regulators also emphatically supervise opportunistic practice and review electric power enterprises' behavior, so that the power industry can perform regulation while keeping the competitive market power and realize the coordination between competition and regulation.

3) Strong independence of the regulators, and good regulatoryeffects

The FERC is a separate entity from the president and Congress. In the U.S., the state's PUCs bear most of the regulatory responsibilities. The state's PUCs are legally independent of other government departments (including the state and the federal government), which are responsible for monitoring and approving retail prices, sales of electricity, procurement and construction plans etc.... ${ }^{[3]}$ Through this setting, regulatory independence is guaranteed, and the state regulators are in a relatively independent position. On one hand, it can insure the fairness of their supervision, effectively safeguard the tangible interests of the local consumers, and promote the continuous development of the power industry in the state; on the other hand, it greatly reduces the intervention and adverse effects brought by the government.
IV. THE ENLIGHTENMENT OF AMERICA'S ELECTRIC POWER REGULATORY REFORM DEVELOPMENT TO CHINA

\section{A. The Reform Process of China's Electric Power Supervision System}

The road of China's power system reform was officially opened in 2002, and its symbol was the promulgation of the power system reform program. According to this scheme, "breaking monopoly and introducing competition" was defined as the goal of reform; the former State Power Company was divided and then realized "separation of the plant network". ${ }^{[4]}$ From 2003 to 2005, the State Council had organized the State Electricity Regulatory Commission (SERC) and promulgated the Electric Power Regulation Act. With the establishment of the National Energy Administration (NEA) and the National Energy Commission (NEC), which respectively undertakes functions of implementation and decision-making of the power industry. At this point, the "coexistence of three carriages" of power management are formed, and the reform of the electricity market is further promoted. ${ }^{[5]}$ However, after reform of the super-ministry system in 2013, the SERC was revoked, and its function was incorporated into the power department of NEA, which make the Chinese power industry return to the situation of 'the unification of government and supervision".

In March 2015, the Central Committee of the Communist Party of China issued the Several Opinions on Further Deepening the Reform of Electric Power System (the "Document No.9"), which pointed out that the reform since 2002, have made great achievements: the commanding system, integration of government administration with enterprise, and non separation between plant and network have been fundamentally changed; the power market system has been formed; the formation mechanism of electricity price has been gradually improved; market-driven transaction and supervision has been actively explored. However, there are still some problems: the transaction mechanism is deficiency; the price relationship is not rationalized; the transformation of government functions is not in place; the development mechanism is not sound; the development and utilization of new and renewable energy resources are facing difficulties.... The power reform program has clearly defined the overall idea of "three liberals, one independence and three reinforcements". According to the system architecture, the "three liberals" refers to the orderly release of competitive link electricity price outside power transmission and distribution, the orderly release of the power distribution business for social capital, the orderly release of generation plans expect for public welfare and regulatory generation. The "one independence" means to promote the relatively independent of trading institutions and standardize operation. The "three reinforcements" means further strengthening government supervision, electric power planning, and safety efficient power operation and reliable power supply. ${ }^{[6]}$ The orderly release of competitive link electricity price outside power transmission and distribution is the biggest highlight of the new scheme of electric reform, which indicates break of the traditional mode of power grid corporation in our country. By gradually opening up the power sale market, we will build pluralistic selling subjects to form a marketization competition pattern. At the same time, energy 
conservation and emission reduction, and green low carbon are placed in an important position in this electricity reform plan. The new electric power reform plan is the inheritance and transcendence of the "Program No. 5" in 2002, and takes into account the demands of reform and the principle of operability, which is more pragmatic and more realistic.

\section{B. The Implications of America's Electric Power Regulatory Reform to China}

The reform of power system can't accomplish at one stroke. It is necessary to develop step by step and draw on the experience of foreign reform. The basic experience of American electric power reform has something illuminating.

\section{1) Enhancing legalization of regulation}

China's power regulatory laws lag behind the needs of actual development. After the super-ministry reform, the Electric Power Regulation Act has gradually lost its role with the repeal of the SERC. The most effective law in power industry is the Power Law of People's Republic of China, which was promulgated in 1995. Although a round of revision had been made in 2015, few of them related to power regulation are still obscure, and supporting rules and regulations have also failed to set up. The legal norms in some details such as pollution discharge and financing of power enterprises are even blank, and there is no electricity legal system covering power, technology, system and environmental protection. American power reform legislate first. The legal norms for current structure of power industry and competition mechanism of electricity wholesale market has been established through the Public Utilities Holding Company Act of 1935 and the Federal Energy Policy Act of 1978. The Federal Power Regulation and Public Utilities Code of various states specify specific rules of power regulation. Besides, America issues such decrees as "Order No. 888" and "Order No. 999" every year to update or supplement the regulatory content of the power industry. ${ }^{[7]}$

2) Intensifying supervision independently and promoting the market's basic role in allocating resources

The revocation of the SERC has resulted in blurred lines between administration and regulation. The state development and reform commission, the ministry of finance, the SASAC, the ministry of environmental protection, the ministry of industry and information and other government departments have undertaken some power supervision duties except for the NEA. In addition, with the relationship between the central and local governments, there are some problems in the power industry of China, such as horizontal supervision fractionally, the terms of reference and power relationship vaguely between longitudinal governments at all levels. In the United States, from a horizontal view, FERC, NARUC and PUCs are independent regulators. From a vertical perspective, America implement the two level supervisory system of federal and state government. The PUCs of various states, which have its own regulatory authority and are generally controlled but not restrained by the FERC. It can not only improve the efficiency and reliability of supervision, but also promote the development of power industry at home. This kind of independent regulatory agencies that makes American regulatory effect is better, the role of market allocation resources is more full. The separation of power generation, distribution and sale and effective supervision make American generation companies more dispersed and more competitive. Therefore, the establishment of power regulatory agencies in the U.S. provides some new ideas for the restructuring of China's power regulators.

3) Reinforcing the regulation of low carbon development in the power industry

As the global cooperation of environmental pollution control, the U.S. Environmental Protection Agency proposed a draft of greenhouse gas emission reduction ,called "clean electricity plan", to strengthen the use of clean energy from the national level in June 2014. The new electric power reform scheme of China has also intensifies the low carbon power development, which presents the concept of green development, and the core value of the power industry should shift from "speeding up development, guaranteeing supply" to "green low-carbon, energy conservation priority". Only by strengthening lawmaking and law enforcement in supervision of power industry, can we realize green development and energy efficiency. American new policy of clean development can be used for reference.

\section{CONCLUSION}

The America's electricity regulation has the characteristics of supervision by law, coordination of competition and supervision and independent supervision. By drawing on these experiences, this paper proposes to strengthen legislation of China's electricity supervision, establish an independent power supervision system and intensify supervision of the low carbon power industry. It hopes that they can provide reference for China's electric power regulatory reform.

\section{ACKNOWLEDGMENT}

This research was financially supported by Special Items Fund of Beijing Municipal Commission of Education. The supports are gratefully acknowledged.

\section{REFERENCES}

[1] Nameless,Full calibre net electric power in the United States in 2016, http://www.360doc.com/content/17/0317/18/502486_637716559.shtml

[2] Nameless, What FERC Does, https://www.ferc.gov/about/ferc-does.asp

[3] M. Dupuy, R. Allen, D. Crossley, R. Weston, F. Kahrl, and K. Porter, International experience of low carbon power sector regulation: U.S., Power Demand Side Management, 2015, pp.61-64. (In Chinese)

[4] Nameless, Power systemreform plan, 2002, pp. 4-6. (In Chinese)

[5] Z. Qin, L. Mingze. X. Long, China power market reform process on. North China Electric Power University, 2014. (In Chinese)

[6] Nameless, Opinions on further deepening the reform of electric power system. 2015. (In Chinese)

[7] Y. Shanshan, the US electricity regulatory legislation, Theory Horizon, 2012, pp. 72-73. (In Chinese) 